\title{
Giant macroprolactinoma and pregnancy
}

\author{
Macroprolactinoma gigante e gravidez
}

Joana Saraiva', Leonor Gomes', Sandra Paiva', Luisa Ruas', Manuela Carvalheiro'

\section{SUMMARY}

1 Department of Endocrinology, Diabetes and Metabolism, Coimbra University Hospital, CHUC, EPE, Coimbra, Portugal

Prolactinomas are a common cause of gonadal dysfunction and infertility. We present the case of a 38-year-old woman with history of amenorrhea and infertility. At seven weeks of pregnancy she presented neuro-ophthalmologic complaints of headaches, diplopia, and right ptosis. The work-up study revealed an invasive pituitary macroadenoma with a maximum diameter of $9 \mathrm{~cm}$ and serum prolactin of $25,800 \mathrm{ng} / \mathrm{mL}$ (3-20). At 12 weeks, she was referred to the Endocrinology Department of the Coimbra University Hospital and started therapy with bromocriptine, initially $5 \mathrm{mg} / \mathrm{day}$ and then at crescent doses. Hyperprolactinemia was rapidly and drastically reduced to $254 \mathrm{ng} / \mathrm{mL}$ three weeks after taking bromocriptine $15 \mathrm{mg} /$ day. Tumoral volume was reduced and there was improvement of III pair paresis. At 38 weeks, a male healthy baby was born. This is a relevant clinical case that illustrates the efficacy and safety of bromocriptine therapy during pregnancy, even in severe cases like this one. Arq Bras Endocrinol Metab. 2013;57(7):558-61

\section{SUMÁRIO}

Correspondence to: Joana Saraiva

Hospitais da Universidade de Coimbra, Praceta Mota Pinto 3000-075 - Coimbra, Portugal joanasaraiva@aeiou.pt endocdiab@huc.min-saude.pt

Received on Aug/11/2012 Accepted on Nov/12/2012
Os prolactinomas são uma causa comum de anovulação e infertilidade. Apresenta-se o caso de uma mulher de 38 anos com antecedentes de amenorreia e infertilidade. Por volta das sete semanas de gestação, iniciaram-se clínica neuro-oftalmológica de cefaleias hemicranianas, ptose palpebral direita e diplopia. $O$ estudo complementar revela a presença de macroadenoma hipofisário com cerca de $9 \mathrm{~cm}$ de maior diâmetro, de crescimento invasivo e destrutivo associado à hiperprolactinemia de $25.800 \mathrm{ng} / \mathrm{mL}$ (3-20). Às 12 semanas, foi referenciada à consulta de Endocrinologia e iniciou terapêutica com bromocriptina $5 \mathrm{mg} / \mathrm{dia}$ em doses crescentes. A prolactina diminuiu drasticamente para 254 $\mathrm{ng} / \mathrm{mL}$ três semanas após, sob $15 \mathrm{mg} /$ dia de bromocriptina. $O$ volume tumoral também foi significativamente reduzido nas suas diferentes extensões. Clinicamente, houve regressão da ptose palpebral e da restante sintomatologia neuro-oftalmológica. 0 parto ocorreu por via vaginal às 38 semanas, com recém-nascido saudável. Este caso clínico é relevante, ilustrando bem a eficácia e a inocuidade da terapêutica com bromocriptina durante toda a gravidez, mesmo em casos graves como este. Arq Bras Endocrinol Metab. 2013;57(7):558-61

\section{INTRODUCTION}

$\mathrm{P}$ rolactinomas are the most common of hormone-secreting pituitary tumors, representing $30 \%$ to $40 \%$ of all pituitary tumors, and are a common cause of anovulation and female infertility $(1,2)$. Hyperprolactinemia leads to gonadal dysfunction by means of several mechanisms: it reduces the amplitude and frequency of the GnRH secretory pulses and consequently the pulsatile secretion of $\mathrm{LH}$; it also has direct action on the ovaries, inhibiting the production of progesterone and estrogen $[3,4)$. The correction of hyperprolactinemia with dopaminergic agonists, cabergoline and bromocriptine, restores ovulation in about $90 \%$ of cases (3). Cabergoline is currently the treatment of choice for symptomatic microadenomas or macroadenomas because it has higher efficacy in normalizing PRL levels and in decreasing tumor size (5).

Restoration of gonadal function by dopaminergic agonists and the possibility of subsequent pregnancy raise two questions: first, the effect of pregnancy itself on tumor growth; and second, the effect of dopaminergic agonists in early fetal development (3). During pregnancy, the risk of tumor growth is minimal in microadenomas $(2.7 \%)$, being higher in macroadenomas $(15-35 \%)(1,3)$. Both drugs appear to be safe when used in the first weeks of pregnancy. However experience with bromocriptine is considerably larger (about 6,000 gestations versus 800$)(2,3)$. In the case of symptomatic tumor growth during pregnancy, clinical guidelines recommend reinstitution of treatment with bromocrip- 
tine $(5,6)$. The use of bromocriptine throughout pregnancy is only described in literature in about 100 cases (3). We describe the case of a giant macroprolactinoma diagnosed during early pregnancy that was successfully treated with bromocriptine throughout pregnancy.

\section{CASE REPORT}

In February 2001, a 38-year-old woman with macroprolactinoma, 12-week pregnant, was referred to the Endocrinology Department of the Coimbra University Hospital. In October 2000, she had been seen in gynecology appointment of another institution for primary infertility and amenorrhea with about two years of evolution. She was given bromocriptine $5 \mathrm{mg}$ id and clomiphene citrate $50 \mathrm{mg}$ id before work-up was started, maintaining the amenorrhea, and she got pregnant. When pregnancy was confirmed, bromocriptine was discontinued. In January 2001 (at around 7 weeks of gestation) she started to complain about headaches, associated with progressively worsening right ptosis, diplopia, and otalgia. Magnetic resonance imaging (MRI) showed a 9 x 5 $\mathrm{x} 5 \mathrm{~cm}$ lesion occupying the base of the skull, with invasive and destructive centrifugal multidirectional growth (sphenoidal sinus, rhinopharynx and nasal cavities, sellar floor and dorsum sellae, posterior fossa, cavernous sinus, carotids, right temporal lobe and apex of the right orbit) (Figure 1). Transnasal biopsy was performed and revealed pituitary adenoma (immunohistochemistry positive synaptophysin and NSE, Ki67 < 1\%). Prolactin (PRL) concentration was 25,800 (non-pregnant normal range $3.0-20.0 \mathrm{ng} / \mathrm{mL}$ ). Other hormonal assays were unremarkable. At that time, an endocrinology appointment was requested for therapeutic guidance.

She was a previously healthy woman without drug use, smoking, or alcohol intake habits. Family history was unremarkable. Ophthalmic examination revealed right ptosis (oculomotor nerve paresis) and strabismus.
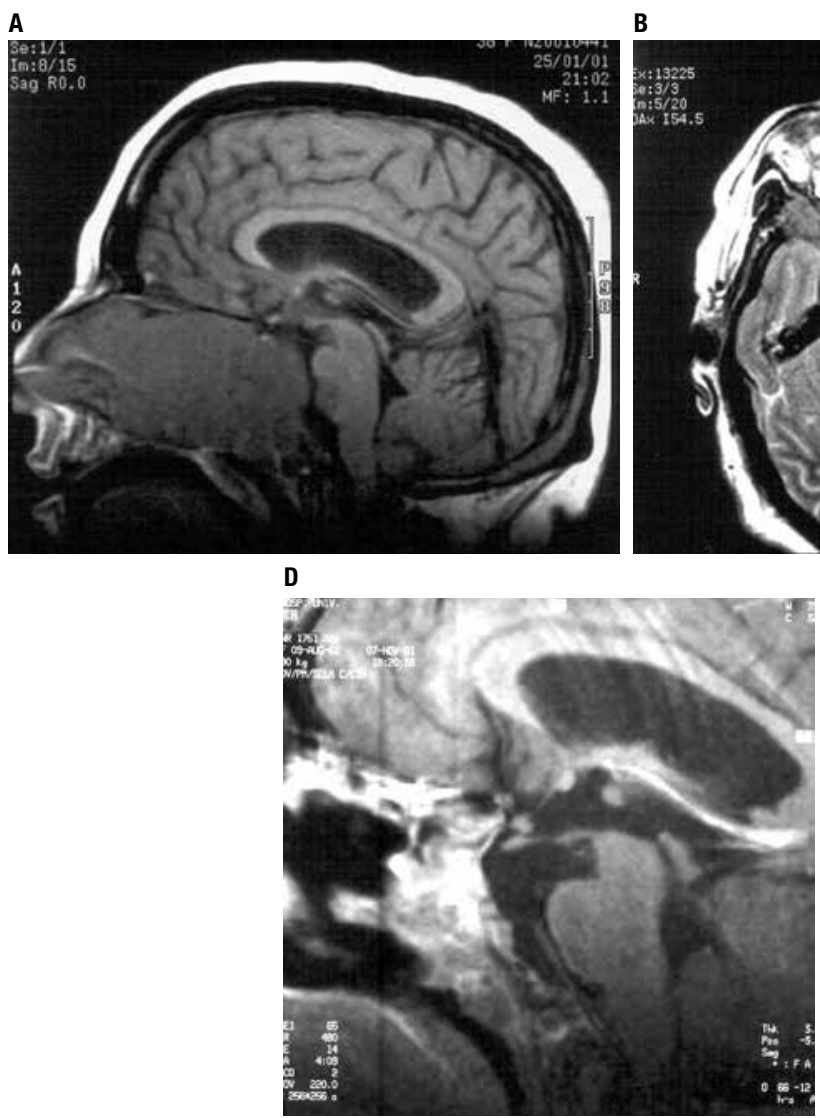

B

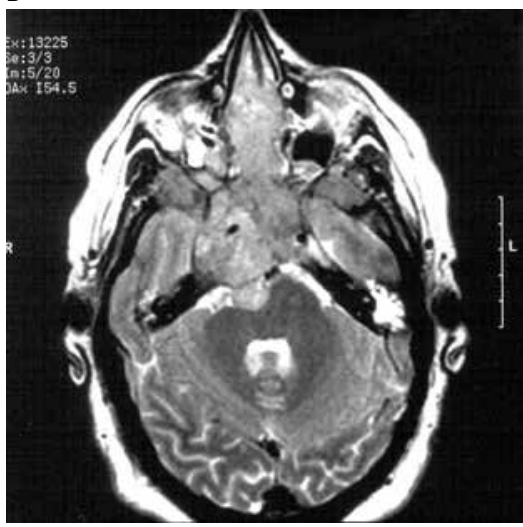

$\mathbf{E}$

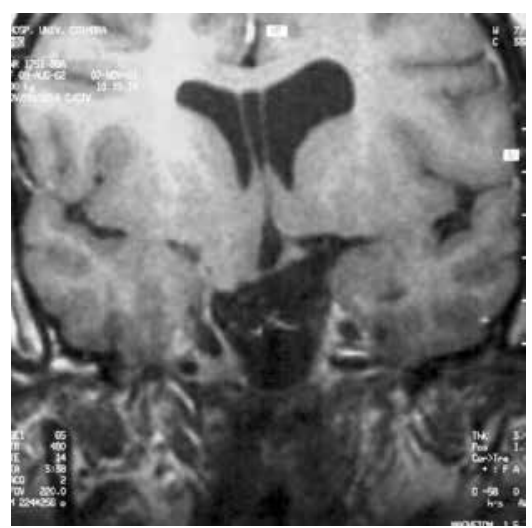

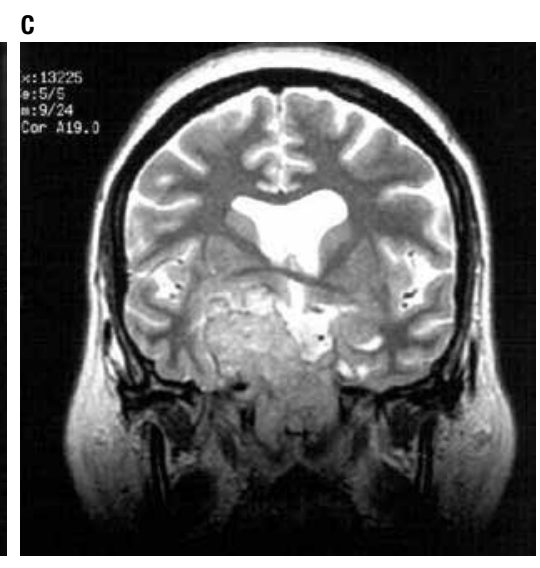

Figure 1. T1 (A) and T2 (B, C) weighted MRI pictures at 12 weeks, showing a large intra-sellar, right para-sellar and suprasellar tumor that fills the sphenoidal sinus, invading the nasal cavity and rinopharynx. Posteriorly, it invades the clivus. Laterally, it invades the right cavernous sinus and shapes the right temporal lobe and right hippocampus, measuring approximately $9 \times 5 \times 5 \mathrm{~cm}$. After therapy, there was a marked decrease in the dimensions of the pituitary macroadenoma, with T1-weighted MRI (D, E) showing residual tumor intra-sellar paramedian right, extending into the sphenoid sinus and posterior portion of the nasal septum. The pituitary stalk and remaining gland are dislocated to the left. 
The visual fields showed loss of fixation to the right. The obstetric assessment with ultrasound was normal with evidence of a fetus of 13 weeks of gestational age and no evidence of anomalies.

Given the tumor characteristics, gestation time and the mother's desire to keep the baby, medical treatment with bromocriptine was chosen, starting with $5 \mathrm{mg}$ at bedtime, together with close monitoring, initially as an inpatient. The dosage of bromocriptine was gradually increased with marked and fast improvement in average levels of PRL: $2,549 \mathrm{ng} / \mathrm{mL}$ with $5 \mathrm{mg} /$ day, $346 \mathrm{ng} /$ $\mathrm{mL}$ with $12.5 \mathrm{mg} /$ day to $254.5 \mathrm{ng} / \mathrm{mL}$ with $15 \mathrm{mg} /$ day. Bromocriptine was well-tolerated and improvement in headache and ptosis was observed. MRI three weeks after starting therapy showed moderate decrease in the macroadenoma size, in its various extensions, more evident in the nasal cavity extent.

The patient was discharged after 20 days, treated with bromocriptine $15 \mathrm{mg}$ /day and folic acid $10 \mathrm{mg}$ id, being followed up as outpatient in the EndocrinologyObstetrics Practice. During follow-up, average PRL was $364.8 \mathrm{ng} / \mathrm{mL}$ and average dose of bromocriptine $17.5 \mathrm{mg} /$ day (Table 1). She was also followed up in the Ophthalmology Practice with almost complete regression of right ptosis.

At 38 weeks, she gave birth by vaginal delivery to a healthy male baby weighing 4,300 g, $51 \mathrm{~cm}$, Apgar 9/10. The post-partum period was uneventful and she did not breastfeed. Treatment with bromocriptine 15 $\mathrm{mg}$ /day was maintained until assessment four months after delivery. She did not report any relevant symptoms, and referred to regular cycles. Ophthalmological examination showed no ptosis and intermittent diplopia. Average PRL was $17 \mathrm{ng} / \mathrm{mL}$. MRI showed marked reduction in tumor volume $(3 \times 2.5 \times 1.5 \mathrm{~cm})$ (Figure 1$)$. During the follow-up at the Endocrinology Practice, prolactin assays always remained within the normal range, and the volume tumor decreased progressively and the dose of bromocriptine was gradually reduced.

In the last evaluation, in 2011 , the patient showed an average PRL $4.1 \mathrm{ng} / \mathrm{mL}$ with $2.5 \mathrm{mg}$ bromocriptine once day. The last MRI at 2011 (Figure 2) showed a cystic area, extending anterior to the sphenoid sinus on the right, and lack of visualization of the right cavernous sinus and mass effect on the left cavernous sinus temporal lobe. Her 10 year-old son showed appropriate psychomotor development for his age, without comorbidities.
Table 1. Prolactin levels in relation to the doses of bromocriptine and gestational weeks

\begin{tabular}{lcc}
\hline Gestation & Prolactin $\mathbf{( n g} / \mathbf{m L})$ & Bromocriptine $(\mathbf{m g})$ \\
\hline 7 weeks & $25,800-26,200$ & No \\
13 weeks & 2,528 & 5 \\
14 weeks & 345 & 12.5 \\
15 weeks & 198 & 15 \\
16 weeks & 244 & 15 \\
17 to 38 weeks (mean) & 364.8 & 17.5 \\
4 months post-partum & 17 & 15 \\
10 years later & 4.1 & 2.5 \\
\hline
\end{tabular}
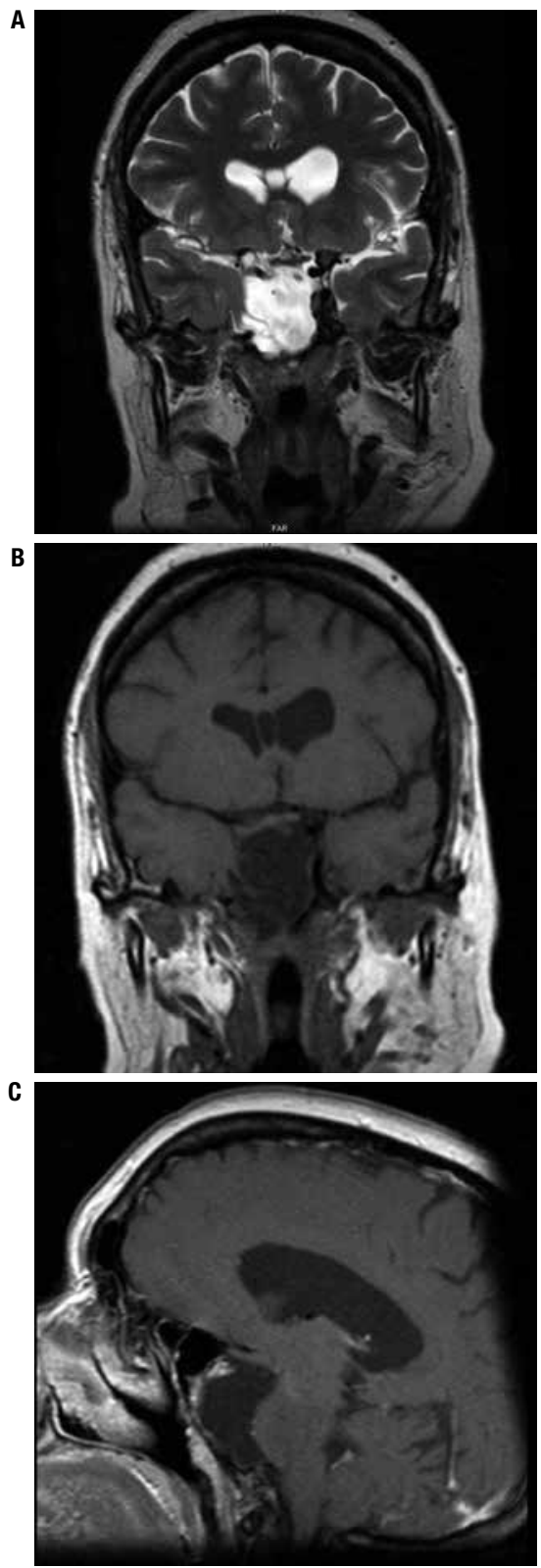

Figure 2. T2 (A) and T1 (B, C) weighted MRI, performed in 2011, showing a cystic area, extending anterior to the sphenoid sinus on the right, lack of visualization of the right cavernous sinus and mass effect on the left cavernous sinus and temporal lobe, measuring approximately $3.7 \times 2.8 \times 2.5 \mathrm{~cm}$. 


\section{DISCUSSION}

We present a patient with an unusual clinical picture, in which the diagnosis of giant macroprolactinoma was only made after conception associated with the particularity of its large dimensions and degree of invasiveness. Prolactinoma diagnosis relies on finding and elevated PRL level after excluding hook effect (5). Biopsy is rarely needed, but in this case due to its imaging characteristics, accessibility trough nasal cavity and without a definitive diagnosis, it was decided to perform such procedure.

Hyperprolactinemia is the cause of infertility in $15 \%$ to $20 \%$ of cases $(2)$. The treatment with dopaminergic agonists is very effective in decreasing serum levels of PRL, and restoration of fertility may be immediate, even before the first normal menstruation $(4,6,7)$. In this particular case, the institution of therapy prior to the work-up of the cause of infertility is likely to have led to a decrease in PRL levels that, in combination with stimulation with clomiphene citrate, enabled the patient to get pregnant.

Soon after the diagnosis of pregnancy, the discontinuation of dopaminergic agonist decreased the time of fetal exposure to the drug but, in the presence of a macroadenoma, poses an increased risk of tumor growth. Therefore, during pregnancy and in the presence of clinical evidence of tumor growth there are several challenges for the physician and the patient herself, and the decision should always be individualized. The latest guidelines recommend reinstitution of therapy with bromocriptine (5). Despite the limited experience of use in these situations, clinical evidence does not seem to show deleterious effects on the fetus. Transsphenoidal surgery may be an alternative, if there is no response to bromocriptine, but any surgery during pregnancy is associated with an increased risk of miscarriage and other complications (2). If the fetus is near term, labor induction may be a valid option. In this patient, pregnancy occurred in an early and fortuitous way, precluding a previous diagnosis of macroprolactinoma and its treatment.

The choice of bromocriptine was very effective in decreasing the levels of PRL and, namely, in the decreasing the tumor size. It is not usual to use such high doses of bromocriptine, but due to such a large tumor it seemed a reasonable option, given the need of rapidly and efficiently decrease PRL levels to allow the correct progress of that pregnancy. Despite high doses of bro- mocriptine used, there were no fetal adverse effects in the short-term, as well as in the subsequent development. Measurement of PRL during pregnancy is not usually recommended, because PRL levels may sometimes not increase in case of tumor enlargement (4-6). In this particular case, given the initial treatment phase and magnitude of the increase in PRL (taking into account the typical values described in the literature) (8), PRL measurement enabled dose adjustment of bromocriptine therapy.

Pregnancy and treatment with bromocriptine conferred a high risk of pituitary apoplexy in this particular case. The inpatient treatment for almost three weeks allowed us to closely monitor this possibility. The extended follow-up of this patient, about 10 years, has shown clinical, analytical and radiologic stability, with a low dose of the dopaminergic agonist. Similar situations that show the beneficial effect of pregnancy on the natural history of prolactinomas are also described in the literature (2).

In conclusion, it seems that this case, despite its severity (in relation with the extension, invasion, surgical accessibility difficulties, and neuro-ophthalmologic complications), illustrates the effectiveness and safety of therapy with bromocriptine. However, it is important to emphasize that the diagnosis should, whenever possible, be prior to pregnancy so that the tumor can be controlled with the consequent reduction of maternal and fetal risks.

Disclosure: no potential conflict of interest relevant to this article was reported.

\section{REFERENCES}

1. Colao A. The prolactinoma. Best Pract Res Clin Endocrinol Metab. 2009;23:575-96.

2. Shibli-Rahhal A, Schechte J. Hyperprolactinemia and infertility. Endoc Metab Clin N Am. 2011;40:837-46.

3. Molitch M. Prolactinoma in pregnancy. Best Pract Res Clin Endocrinol Metab. 2011;25:885-96.

4. Mancini T, Casanueva F, Giustina A. Hyperprolactinemia and prolactinomas. Endocrinol Metab Clin N Am. 2008;37:67-99.

5. Melmed S, Casanueva F, Hoffman A, Kleinberg DL, Montori VM, Schlechte JA, et al. Diagnosis and treatment of hyperprolactinemia: an Endocrine Society clinical practice guideline. J Clin Endocrinol Metab. 2011;96:273-88.

6. Casanueva F, Molitch ME, Schlechte JA, et al. Guidelines of the Pituitary Society for the diagnosis and management of prolactinomas. Clin Endocrinol. 2006;65:265-73.

7. Thorner M, Harrison D, Bronstein M. Hyperprolactinemia. 2011;6: 1-8. Disponível em: www.endotext.org.

8. Bronstein M. Prolactinomas and pregnancy. Pituitary. 2005;8:31-8. 